\title{
Issues and challenges in managing curriculum change in primary schools: A case study of managing Year Four History Curriculum in the District of Kuala Selangor, Malaysia
}

\author{
Thangamalar Paramasivam ${ }^{* 1}$ and Nagendralingan Ratnavadivel ${ }^{2}$ \\ ${ }^{1}$ Sekolah Kebangsaan Bukit Badong, Bestari Jaya, Selangor, Malaysia, \\ ${ }^{2}$ Sultan Idris Education University, Malaysia
}

Received: 9 March 2018; Accepted: 9 May 2018; Published: 4 June 2018

The case study aimed to explore and explain the issues and challenges experienced in the management of curriculum change in primary schools. This was done by analysing the management of curriculum change brought about by the introduction the History curriculum for the Year Four Primary Schools Standard based Curriculum. This case study used a descriptive- interpretative approach grounded in the qualitative research tradition. Precisely, it is an instrumental case study. Data was collected through analysis of documents, in-depth interviewing (based on semi-structured interviews) and the direct observations of learning and teaching of History lessons. It was located within the context of eight selected schools (four National Primary Schools and four Tamil Type National Primary schools). A total of twenty eight respondents were interviewed. The findings show that the respondents did face issues and challenges in managing the Year Four History curriculum. They were pertaining to curriculum content, teaching and learning process, assessment, availability and utilization of time, training and staff development, physical facilities. The findings of this study can assist curriculum developers, curriculum administrators, school management team and teachers in improving quality of primary school curriculum change management.

Keywords: Managing curriculum change, issues and challenges, primary school, history curriculum

\section{Introduction}

This article is grounded in the data analysis and interpretation of a doctoral study entitled. $A n$ Evaluation of the Management of Primary School Curriculum Change: A case study of the Year Four Standard Based Primary School History Curriculum. The case study aimed to explore and explain the issues and problems pertaining to the management of curriculum change in primary schools. This was done by analysing and evaluating the management of curriculum change brought about by the introduction the History curriculum for the Year Four Standard-Based Primary School Curriculum (KSSR being its acronym in the Malay language). It was located within the context of eight selected schools (four National Type

\footnotetext{
Email: malar9739@yahoo.com
} 
schools and four Tamil Vernacular schools) and views of other critical respondents in the district of Kuala Selangor. According to Ratnavadivel (1995), often problems related to the management a new curriculum stem from the weaknesses of curriculum change management models and strategies used. Hence, this study also analyzed the change models and strategies used in the management of primary school curriculum change and their suitability for the realization of curriculum goals. However, this article only focuses on the issues and challenges pertaining to the management of curriculum change.

Bernstein (2003) considers curriculum, pedagogy and evaluation to be the three message systems through which educational knowledge can be considered to be realized. He elaborates it in as follows: Curriculum defines what counts as valid knowledge, pedagogy defines what counts as valid transmission of knowledge, and evaluation defines what counts as valid realization of this knowledge on the part of the taught. The term educational knowledge code refers to the underlying principles which shape curriculum, pedagogy and evaluation (ibid). The school curriculum is actually weaved from the requirements and aspirations of the nation and ought to be viewed as an integral part of national development. The curriculum actually reflects and reinforces the ideals, aspirations, values, ideas, knowledge, skills that the nation considers important and that which is cherished by the nation. It is actually a blueprint or template for the future development of the nation. In many developing nations the curriculum is actually aligned to the national development goals of the nations, particularly so in a nation where the system of education is highly centralized and determined by the political elite of the nation. Blenkin, Edwards and Kelly (1992), in discussing change and the curriculum, are of the view that changes in the curriculum practices actually reflect parallel changes in our ways of viewing and conceptualizing curriculum which are associated with new points of focus and new forms of educational discourse.

In Malaysia, the curriculum changes that took place as a result of the change from the former primary school curriculum (KLSR being its acronym in the Malay Language) to the New Primary School Curriculum (1983), later (1993) referred to as the Integrated Primary School Curriculum (KBSR being its acronym in the Malay Language) necessitated new requirements and implications in terms of curriculum, content, pedagogy and assessment. KBSR also resulted in new implications for the role of pupils and teachers whereby learning and teaching became more interactive based on a horizontal and not vertical relationship between teachers and pupils. The role of the teacher as a facilitator became the expected norm. KBSR was developed after considering the in-depth recommendations of the Cabinet Committee Report, 1979. The Report places emphasis on aspects of humanitarian development related to manpower needs and education. The effort to translate the recommendations of the Cabinet Committee on the development of humanitarian aspects has been included in the development of primary school curriculum. So, in 1993, the primary school integrated curriculum began to replace existing primary school curriculum through inclusion of elements that transcend the curriculum and the introduction of new subjects such as, Living Skills, Science and Local Studies.

Curriculum is a dynamic on-going process orchestrated by the changing and emerging political, economic and social demands of the nation. The change is often aimed at improving the quality and quantity of education. Change can take the form of reforms or innovations. Reforms are mandated whereas innovations are persuasions, for example, KBSR was a reform but the need to use group methods for teaching and learning was a persuasion in that it was just a recommended strategy. There can be several innovations within a reform. Both reforms and innovations intend to bring about change. However, they can result in reforms or innovations without change (Ratnavadivel, 1995). The Standard-Based Primary School Curriculum (KSSR) is an educational transformation, where the process is geared towards bringing about a holistic change to the existing school curriculum involving the 
change of form, organization, content, pedagogy, time allocation, assessment method, materials and curriculum management in schools. KSSR began to be implemented in stages in Year One beginning of 2011 at primary school level throughout Malaysia. KSSR is based on four principles that support KBSR namely integrated approach, individual development as a whole, the same educational opportunity for students, and lifelong education (Ministry of Education Malaysia, 2010).

KSSR is divided into six key areas: communication, physical development and aesthetics, humanity, self-esteem, science and technology, spirituality, attitudes and values. Based on the Ministry of Education Malaysia (2010), the key area of communication involves the integration of spoken and non-verbal language skills while interacting. In this key area, there are core subjects and elective subjects. The core subjects are Bahasa Malaysia, English, Tamil (SRJKT) and Chinese (SRJKC). The elective subjects are Arabic, Chinese (SK), Tamil (SK), Iban, Semai and Kadazandusun languages. Science, Mathematics, Design and Communication, Information and Communication Technology subjects are in the key area of science and technology. In the key area of physical and aesthetic development, the subjects are Physical Education, Health Education, Music and Visual Arts. While in the key area of spirituality, attitudes and values, the subject of Islamic Education is taught to Muslim Islamic pupils and Moral Education is taught to non-Muslim pupils. Furthermore, the subject of History is a core subject in the key area of humanities. Finally, the key area of self-help is carried out through curriculum and co-curricular activities. KSSR also aims to equip pupils with 21 st century skills and attitudes so that they can equip themselves with Intelligence Quotient (IQ) and Emotional Intelligence (EQ) required to produce human capital that can compete globally. The introduction of KSSR is a holistic change in curriculum, pedagogy and assessment based on "constructive alignment" approach. KSSR has also to be viewed in relation to the Malaysia Education Blueprint 2013-2025 (2012). The Blueprint has identified access, quality, equity, unity and efficiency as the five system aspirations for the Malaysian education system. Furthermore, the Blueprint has also emphasized knowledge, thinking skills, leadership skills, bilingual proficiency, ethics and spirituality and national identity as the six attributes needed by every pupil to be globally competitive. It means the curriculum, pedagogy and assessment have been designed to help develop Higher Order Thinking Skills (HOTS) among pupils and create quality learning. After two years of KSSR's introduction, in 2014, the new subject of History were introduced at primary level due to its importance for students to understand communities and countries. History as a subject was introduced at the primary level so that pupils were exposed to the knowledge and skills of History at the beginning before continuing their secondary education. Exposure at elementary level can help pupils acquire and master the knowledge and skills of History. In addition, the civic and citizenship elements contained in the subject are intended to produce citizens with national identity; forming Malaysians who support racial unity; to produce patriotic minded students who understand and appreciate the history of Malaysia (Ministry of Education, 2013). The subject covers most of the six attributes that need to be developed in students from the primary level. The introduction of History as a subject at the primary level also represented a significant change for the teachers who had been teaching the subject of Local Studies which only some aspects of history. Moreover most teachers at the primary school level were not trained as history teachers. Therefore, it is relevant for primary school curriculum change management to be studied through the management of the subject of History for Year Four that was introduced in 2014. 
Issues and challenges in managing curriculum change in primary schools: A case study of managing Year Four History Curriculum in the District of Kuala Selangor, Malaysia

\section{Methodology}

This case study used a descriptive- interpretative approach grounded in the qualitative research tradition. It is an instrumental case study. Data collection methods consisted of indepth interviews, documentation and classroom observation. Respondents of this research consisted of eight year four history teachers, eight headmasters (GB being its acronym in the Malay language, eight senior assistants of curriculum (GPK Kurikulum being its acronym in the Malay language), an officer from Curriculum Development Division (BPK being its acronym in the Malay Language), one officer from State Education Department (JPN being its acronym in the Malay language), an officer from the District Education Office (PPD being its acronym in the Malay language) and a National Trainer (JUK being its acronym in the Malay Language). A total of eight teachers were observed twice each bringing to a total of 16 observation sessions. Each observation also involved brief clarifications about the focus of their lessons, before the lesson, and on what transpired during the lesson, after the observations. Analysis of data was thematic. The themes emerged from the analysis of Data. Six salient themes that emerged were: skills, content, pedagogy, assessment, support system, training and leadership. Finally, the research has proposed a curriculum change management model for improving the quality of primary school curriculum change management.

In terms of procedure and process, the study was divided into four phases. As this study is an instrumental case study, the first phase of the study focused on the study of general curriculum changes from Primary School New Curriculum (1982) to Standard- Based Primary School Curriculum (2011) and specifically for the subject of Local Studies and History for Year Four (research questions 1 and 2). The subject of history for Year Four was selected because the introduction of the History at primary level is a new change in primary school curriculum and is taught in Year Four. Next, based on the findings pertaining to research questions 1 and 2, the implications of curriculum change for curriculum change management (research question 3) were discussed. Furthermore, the second phase also involved analysing the problems that exist in the management of curriculum change as expressed by History teachers, head masters, and senior assistants of curriculum, National Trainer, an officer from District Education Office, State Education Department and Curriculum Development Division (research question 4 question). Based on the findings of the analysis, a database based on the meta-interpretation process was built. In the third phase, the findings from the database were used to make an analysis of curriculum change management based on curriculum change management theory, models and strategies (research question 5). The fourth phase involved the evaluation of curriculum change management based on the Countenance Model (Robert Stake, 1967) and the proposed model of primary school curriculum change management to improve the quality of curriculum change management of primary schools so that parallels between the written curriculum, the taught curriculum and the assessed curriculum is analysed (research question 6). However, this article only focuses on the issues and challenges pertaining to the management of curriculum change.

\section{Results and discussion}

\section{The epistemology of the curriculum}

Firstly, there is a need to explore the epistemology of the curriculum. What is the philosophy underlying the curriculum in terms of the values, knowledge and skills it proposes? What is the theory of knowledge underlying the curriculum and what are the values, knowledge and skills that are being conveyed through it? Education in Malaysia is guided by the National Education Philosophy (NEP) which reads as follows: 


\begin{abstract}
Education in Malaysia is an on-going effort towards further developing the potential of individuals in a holistic and integrated manner, so as to produce individuals who are intellectually, spiritually, emotionally and physically balanced and harmonious, based on a firm belief in and devotion to God. Such an effort is designed to produce Malaysian citizens who are knowledgeable and competent, who possess high moral standards, and who are responsible and capable of achieving high level of personal well-being as well as being able to contribute to the harmony and betterment of the family, the society and the nation at large.
\end{abstract}

(Ministry of Education Malaysia, 1988)

From the statement of the Philosophy it is apparent that the term "on-going" indicates that the philosophy subscribes to lifelong learning. The term "further developing" indicates that the underlying assumption is that that students do not come as "clean slates" they have their own knowledge, abilities and values based on their own experiences. The philosophy also emphasizes the development of the mind, body and soul in a balanced and harmonious manner which relate to the cognitive, psychomotor and affective domains of learning. This has implications for the theories, approaches, strategies, methods and techniques of teaching and learning employed in the process of teaching and learning that enable the appropriate quality learning. The Philosophy is also an inclusive philosophy in that it moves from the individual to family, society and nation. It has implications for the role of the teacher and the learner. The NEP is the basic foundation for all education programmes. All education programmes are developed in the form of a curriculum. In the Education (National Curriculum) regulations 1997, defines National Curriculum as:

\begin{abstract}
'An educational programme of education which includes curricular and co-curricular activities that cover all knowledge, skills, norms, values, cultural aspects and beliefs to help the full development of a student from the physical, religious, mental and emotional aspects and also to inculcate and improve desired moral values and to deliver knowledge'
\end{abstract}

In addition to the demands of the Philosophy, the designing and implementation of KSSR is also based on the developing of six attributes spelt out in the Blueprint, $21^{\text {st }}$ Century skills, spirit of unity and racial harmony and communication skills. The responsibility falls on the shoulders of teacher to engage, nurture and develop their pupils to be effective competitors locally and globally. The Standard-Based Primary School Curriculum for History emphasizes the cognitive, affective and psychomotor domains, as well as applying the added value elements of the new millennium such as thinking skills, information and communication technology skills, multiple intelligence skills, future studies and lifelong learning. This curriculum also emphasizes the inculcation and nurturing of noble values, patriotic spirit, elements of citizenship and civic values. All these elements are expected to be applied by pupils in everyday life. This curriculum is an educational transformation that emphasizes student-centered and fun learning methods. The History curriculum has been developed to help teachers to become more proactive, dynamic and progressive as well as to enhance their understanding of the goals, objectives and content of the Standard-Based Primary School Curriculum. In addition, the History curriculum can help teachers provide and implement effective teaching and learning activities. Appreciation of patriotic spirit, citizenship element and civic values can be realized based on the title in the content standard as well as the standard of learning. 
As stated earlier, History is a core subject in the Standard-Based Primary School Curriculum (KSSR) that all pupils must take beginning from the fourth year in Level Two of the primary school. This is to inculcate in pupil's an understanding of the History subject in the early stages so that pupils acquire and master the knowledge and skills of History. The History curriculum integrates knowledge, skills, elements of citizenship and civic values in its implementation both inside and out of the classroom. In KSSR, the elements of citizenship and civic values taught through the History course act as basics for producing a citizens who posses national identity. Basically, these elements are expected to nurture Malaysian citizens who subscribe to social cohesion and national integration. Hence, knowledge and understanding of the historical aspects of the nation is supposed to produce patriotic-minded pupils by giving exposure in analyzing and assessing historical facts rationally. Contents of the History curriculum aim to educate pupils to understand the background of the country and its history by looking at the early history, sovereignty and glory of the nation. The approach employs an arrangement by topics so that pupils can appreciate the history of the nation and its glory.

The purpose of the Four Year History subjects emphasizes the development of pupil's thinking skills through the understanding of human behavior by studying the causes and consequences of historical actions and events. Identifying causal relationships is an effort to enable students to understand the cause of a historical event and the implications of the historical event. This goal activates pupil cognition to think so that pupils can find the cause and effect of historic events. This goal seeks to enable pupils to think in complex situations rationally and logically so as to be able to make decisions and find solutions to the problem and also avoid undesirable historical events. Without these analytical skills, pupils will be less able to make rational decisions affecting their personal lives, families, communities and about countries that interfere with peace and harmony. Hence, the objective of the Year Four History in KSSR aims to produce pupils who can think analytically so that benefits can be obtained for themselves, families, communities and countries in maintaining peace and harmony of the nation.

The Year Four History curriculum has 12 objectives that must be mastered by pupils. Every History teacher who knows and understands the objectives of the History subject should be able to produce effective teaching and learning processes. This is because the objectives of the History subject states the requirement of the History curriculum that every student needs to achieve over a year of teaching and learning. Among the objectives of the History subject are:

(a) Understanding past events through curiosity;

(b) Identifying various sources of historical information;

(c) Understanding ideas, concepts, and elements of cause and effect in history;

(d) Expressing the importance of history in life by taking lessons from historical events in an effort to strengthen the atmosphere of harmony;

(e) Stating various forms of presentation and findings from interpretation of historical studies;

(f) Evaluating national heritage in the context of local, state and global areas;

(g) Understanding the process of building human civilization that affects the life of society;

(h) Explaining the past and present life and culture of society in Malaysia;

(i) Understanding the racial position in the context of the location and the formation of the people as a consolidation of racial understanding;

(j) Understanding national challenges in the context of maintaining national sovereignty for the development of national identity; 
(k) Identifying the efforts and contributions of national leaders and expressing their pride and respect for them and

(l) Assessing the achievement and progress of the country in the political, economic, and social fields.

\section{Curriculum coherence: The experience of learning}

\section{Curriculum content}

The findings of the study showed that the teachers encountered problems with Year Four's History subject content. Many topics and subtopics caused some problems to the teachers and pupils in terms of clarity of understanding. The impact of "content overloaded" caused teachers to face difficulty in teaching all topics provided in the Year Four textbook. It caused teachers to focus only on the content coverage and neglecting the actual knowledge, skills and values that should be acquired by the students and it led to decreased interest in learning History by the pupils.

Therefore, the Curriculum Development Division must be made aware that the over emphasis on knowledge and information does not prepare the pupils to live in the challenging word (Stabback, 2016). So, the balance is required between time allocation and the content to ensure the pupils to gain the skills, values and attitudes. Furthermore, some senior assistants curriculum and headmasters complained that the facts in History content looked different when compared to actual history facts. The differences in facts caused teachers to lose motivation in teaching History. Stabback (2016) too said that the lack of alignment between the knowledge can lead to confusion and poor teaching and learning process. This affects teacher's confidence in the History subject as well as the quality of the teaching and learning process of the subject. This issue was also acknowledged by the officer in the State Education Department stated that some of the facts in the history textbook were wrong and they had wrongly printed historical facts. Besides that, a headmaster who had been a National Trainer for previous curriculum (Primary School Integrated Curriculum), complained that the difficulty in Standard Curriculum and Assessment Documents caused the teachers to encounter problems in the teaching process. Teachers as curriculum implementers, refer to the content to plan and implement the teaching and learning process. Then the teacher determines the learning objective and the appropriate activities so that students can master the content. This means that the content is viewed as a knowledge field that includes facts, concepts and theories that the students need to master so that the objectives of a subject are achieved. Therefore, it is important to ensure that all structured content is taught to pupils to achieve the desired goal. The introduction of the History subjects at the primary level also needs to achieve the desired goal. It is therefore important to solve problems related to the subject matter of the History so that pupils acquire the desired knowledge, skills and values.

\section{Teaching and learning}

The process of teaching and learning is very important in the management of the curriculum because it works to achieve the desired learning objectives. In short, the objectives of a curriculum is implemented the through teaching and learning processes to bring about the desired change among pupils. Through the process of teaching and learning, teachers transform their written curriculum into the taught curriculum. The extent to which the written curriculum is applied in practice is highly dependent on the ability of teachers to understand the content, the choice of teaching and learning methods and the appropriate teaching aids, 
planning and implementing instructional plans, assessments and reflections. Therefore, it is important to explore the problems that exist in the implementation of Four Year History subjects at primary level.

Teachers criticized the process of teaching and learning of the subjects of Year Four History. Problems at school level exist when teachers are aware of and recognize the techniques and learning suggested in Curriculum and Assessment Standard Documents (CASD) but failed to apply them because teachers modify teaching and learning methods to suit pupil's ability. The study revealed that pupils are faced with difficulties in accepting new teaching and learning methods because of environmental influences affecting their learning style. The study revealed that most Tamil Type National Schools are located in the oil palm plantation area. This shows that the majority pupils are less vulnerable to the outside world. At the same time, parents working in plantation areas are less capable of providing homebased internet facilities. This causes the intellectual level of rural pupils to remain low. The effect is that teachers face difficulties in applying new ICT based teaching and learning methods and facilitating the chosen techniques required to enable their pupils to master the desired learning objectives. So, it is important to make sure the written curriculum is inclusive to help the students from different socio- economic circumstances to achieve their potential. According to Hibbard, Leonard and Pai (2015), social justice is importart in curriculum designing process to help students from different socio- economic background to excel in their studies equally with other well being students.

Furthermore, from the perspective of a senior assistant of curriculum, teaching and learning process of the previous curriculum is said to be effective compared to the recent curriculum that has the influence of ICT. This shows that there were some advantages in the previous curriculum so that teaching and learning process was more effective. This is because the previous curriculum was less burden to teachers and the lesser number of subjects enabled teachers to focus more effectively on teaching. In addition to that, when compared with Malaysia's previous curriculum before 1993 untill 2003, the recent Standard-Based Primary School Curriculum involves various elements to be taught to students such as HOTS, reasoning, creativity, innovation, entrepreneurship and ICT. Additionally, the number of subjects increased from five subjects to nine to fourteen subjects in the Standard-Based Primary School Curriculum. In addition, aspects of assessment involve transit forms, filling student's achievement in School-Based Assessment system and managing the student's records in a filing system. These administrative demands caused teachers to lose focus on the teaching and learning process. This has a negative impact on the effective implementation of the teaching and learning process. Research by Majoni (2017) indicates that an overloaded curriculum leads to negative impact on teacher's effectiveness in teaching process. Therefore, this Standard- Based Primary School Curriculum must be revised again from broad curriculum to narrow so that the teacher's know their focus for teaching an able to perform well in classroom.

Next, from the headmaster's perspective, problems exists when the teaching and learning process of the History subject is too content oriented. If the teaching and learning process focuses on the presentation of facts or theories, the outcomes desired by the Ministry of Education through the History course are not met. When the teaching and learning process is centered on teachers, pupils simply become passive listeners without understanding and applying knowledge, skills and values in their daily life. The findings showed that the process of teaching and learning History only helps pupils to acquire historical knowledge in an academic manner only. The inculcation and internalization of noble values required in social life could not be realized. Content based teaching learning process was by the non option teachers who do not have passion in teaching History. Research by Williams et al. (2018) and Keller et al. (2017) showed that the skilled teachers are more likely perform well compared to 
non skilled teachers. Therefore, it is important for MOE to train and provide more skilled History teachers to help the pupils to achieve the intended curriculum aims and objectives.

\section{Higher Order Thinking Skills (HOTS)}

History teachers have encountered problem in implementing of HOTS. Results showed that application of HOTS questions among pupils with moderate and weak achievements levels is ineffective. The HOTS questions can only be answered and resolved by clever pupils. Whereas, many pupils who are weak and moderate cannot answer questions that require higher order thinking skills. Data from interviews revealed that the reason pupils are less capable of thinking at a higher level is because they were from a rural areas where they are not challenged to think at a higher level. The rural environment in which they experienced their educational socialization caused the pupils to less capable of explaining the concepts and ideas in a cohesive and logical manner. It is again about designing a curriculum for equity and excellence as discoverd by Hibbard, Leonard and Pai (2015). In Malaysia's Education Blueprint (2013-2025), thinking skills has been identified as one of the six attributes that pupils were required to have in order to compete internationally. Thinking skills have been emphasized since 1994 when the Primary School Integrated Curriculum was introduced. In 1994, focus was given to Critical and Creative Thinking (CCT) to enable students to solve problems and make rational decisions. The CCT has been implemented through pedagogy and curriculum. Meanwhile, according to the Ministry of Education Malaysia (2014), the Higher Order Thinking Skills (HOTS) were introduced again through the Standard Based Primary School Curriculum starting from 2011. This new curriculum focuses on elements of HOTS such as analyzing, applying, evaluating and creating. The application of HOTS is emphasized in the curriculum, pedagogy, assessment and supported through co-curricular activities, community support, private sector development, and resources. This shows that changes in the curriculum, pedagogy and assessment were introduced to develop pupils HOTS in the classroom so that pupils can make decisions, solve problems, innovate and create ideas. Therefore, it is important to address the problems faced by teachers in applying HOTS through the teaching and learning of History for year four pupils.

\section{Assessment in the curriculum}

Data from interviews indicate that all eight teachers who were respondents of the study lacked sufficient understanding about how to structure the assessment for History Subject. According to a History teacher and also a Pedagogical Trainer for History Subject, the allocation for assessment was a percentage are $40 \%$ for objectives questions, $30 \%$ for structured questions and $30 \%$ for course work. The findings from teachers revealed that they focused only on objective and structured questions and not on course work. When the teachers do not follow the assessment format, the goal of conducting the assessment is not achieved. This is because the objective questions, structure and course work have their respective roles in developing the knowledge, skills and values that have been learned during the teaching and learning process. In addition, there are issues related to course work. According to a senior assistant curriculum, course work is less helpful in improving the student's knowledge, skills and values. It was happened because the students were making photocopies of the material their textbooks and paste them in their scrapbooks as homework exercise. Other than that, a school principal questioned the validity and reliability of the School Based Assessment system when he noticed that some teachers just "tick" in the offline assessment system without judging the students real progress. Besides that, the National Trainer found that the History teachers also encountered problems in storing pupils records. Teachers still do not understand the file 
management system for storing students records due to lack of understanding in managing student's results. The National Trainer recommends that there should be cooperation between Malaysian Examination Board and Ministry of Education (MoE) so that the files are properly and effectively coordinated. According to the Curriculum Development Division (2010), the aim of assessment is to track student achievement during the teaching and learning process. Through assessment, teachers can evaluate student achievement in acquiring knowledge, skills and value acquisition. At the same time, ongoing assessments aim to see the progress, development, performance and achievement of students in terms of knowledge, skills and values based on content standards and standards of learning have been set. It is therefore important to solve the problems faced by the teachers in terms of assessment so that the aims of School Based Assessment are achieved.

\section{Curriculum resourcing}

\section{The availability and utilization of time}

Time allocation for a subject plays an important role in ensuring the curriculum is implemented effectively. If a subject has minimum time allocation, the teacher has less time to engage pupils to think, reflect, explore and solve problems. The study revealed that there were problems too due to the lack of time allocation for the subject of History. Time allocated is just 60 minutes per week for all types of primary schools. This means that teachers engage in the teaching and learning of History subjects only once a week. The findings show that the teachers, senior assistants of curriculum and school headmasters from both types of schools are of the opinion that the allocation of one hour a week is insufficient to carry out the process of teaching and learning of the History effectively. The lack of availability of time also impacted on the utilization of time. Various negative impacts such as teacher-centered and content based teaching and learning were influenced the utilization of time. It also resulted in pupils becoming less interested in learning History. The gap between lessons also meant that most pupils tend to forget the previous lesson and also fail to complete the homework given. This has led to insufficient mastery of the knowledge, skills and special values of the subjects. The desire to educate pupils with a wholistic, intellectually spiritually, emotionally and physically balanced development became difficult. According to Stabback (2016), a good quality of curriculum must have a balance between time allocation and content. Therefore, it is important to solve the problems associated with time allocation for the subject of History which is a very important subject for cultivating elements of citizenship, civic values and higher-order thinking skills in the students.

\section{Training and staff development}

\section{Curriculum Dissemination Course}

The quality and proficiency of teachers will impact on the quality of learning experienced by the pupils. The effectiveness of the implementation of the new curriculum depends on the quality and quantity of teachers. Teachers' quality is the ability of teachers to implement curriculum change effectively based on Pedagogical Content Knowledge (PCK) which not only pertains to mastery of teaching and pedagogy but also the ability amalgamate both to bring about meaningful learning for the pupils. In addition the teacher should also be adapt at using technology to facilitate effective teaching and learning. Hence the acquisition of Technological PCK is important for the effective management of the curriculum at the level 
classroom discourse. This is because teachers' proficiency in TPCK is important in ensuring that pupils gain an understanding of the subjects they are studying. History Year Four subject is a new curriculum at primary school which has a lot of knowledge, skills and values that teachers need to master before implementing in the teaching and learning process. This means that, the expected quality of the curriculum depends on the quality of the teacher who is implementing the curriculum of History subjects. Therefore, it is important to solve the problems that existed regarding non-option teacher teaches History subjects.

Another significant problem is teaching of History by the teachers who are nonoptionists. The teachers, senior assistants of curriculum and school head masters from both school commented on lack of effectiveness of teaching and learning conducted by teachers who are not history optionists. They lack of TPCK skills pertaining to the teaching of history. Walker (2016) said that degree of quality in teaching and learning depends on the teacher's level of PCK proficiency in the the subject concerned. Since MOE has not provided History option teachers to teach history in primary schools, there is a need to provide the required training for non-History option teachers to teach history. The History teachers should be trained early in Teacher's Intuition to ensure the effective implementation of History. Findings from a National Trainer who have carried out the Standard Based Primary School Curriculum for Year Four history subject dissemination course at the national level revealed that some of the teachers who attended the dissemination course did not understand the implementation of the History subject because he/she was not from a History Option. When there is a problem of low understanding of the History subjects among non-option teachers, the process of teaching and learning of the becomes ineffective. This issue was also agreed by the officers in DEO.

The dissemination course for History teachers who teach History for Year Four has certain advantages over the course of dissemination of other subjects. Findings from the Pedagogical Trainer revealed that teachers at the course experienced Professional Learning Communities (PLC). PLC concepts in the dissemination course are applied to guide teachers to create an effective teaching and learning process together with other teachers. PLC is a cycle where teachers conduct action research and inquiry together with other peer teachers to improve understanding and achievement of pupils. Therefore, the adoption of PLC in History pedagogy is a good move introduced by the State Education Department to improve the effectiveness of teaching and learning process. However, there are also some weaknesses in the curriculum dissemination course that were identified after interviewing the History teachers, senior assistants curriculum and National Trainer. There are also cases where teachers participate in curriculum dissemination courses only with the Curriculum and Assessment Standard Documents (CASD) only. Should the teaching modules be given to teachers as teachers who attend the course? This will offer the opportunity to identify the restructuring of the content that needs to be taught to be restricted and the teacher fails to prepare mentally early. When teachers are supplied with textbooks and CASD, teachers will have the opportunity to link CASD with textbooks to gain an understanding of the content to be taught. At the same time, teachers will also have the opportunity to present any questions and problems with CASD and textbooks with National Trainer in the course such as the alignment between CASD and textbooks, clarity of content and accuracy of historical facts. This can help Trainer in identifying problems that exist before the implementation of the History subject and report to stakeholders for immediate action can be taken. Besides that, results from teachers showed the dissemination course had some problems such National Trainer lack of time to explain the CASD. Lack of time causes the National Trainer to not explain the CASD as a whole. This affects the quality of the curriculum and the understanding of history teachers. Whereas from the National Trainer perspective, the problem that occurred after the dissemination of the History Subject course was the lack of information. The 
information presented during the curriculum dissemination course was not fully communicated by course participants to teachers and administrators at the school level. At school level, the teacher only conducts an in house training for an hour. The effect is that teachers and administrators do not gain clarity and deep understanding of the subjects of History. This affects the effective implementation of the History curriculum.

Findings from Nor Haslynda (2014) show that there was misalignment between the written curriculum and taught curriculum in Standard- Based Primary School Curriculum (English Subject) caused by the shortcomings in dissemination strategy and training. So, it is important to examine the problems associated with the curriculum dissemination course so that existing weaknesses are improved so that the curriculum is effectively disseminated. The curriculum dissemination course plays a very important role in exposing teachers to the curriculum changes that have taken place. Through the curriculum dissemination course, not only benefits teachers, but also the teaching profession, school organization and the public. Teachers will be more competent and have the opportunity to acquire knowledge and skills related subjects to be taught. After a curriculum dissemination course, the teacher seeks to guide, manage and lead a colleague in implementing a new curriculum at the school level. However, the quality of curriculum dissemination at the school level depends largely on the quality of curriculum dissemination at the district level. At the same time, the quality of the implementation of the new curriculum also depends on the effectiveness of curriculum dissemination from the top-bottom level. It is therefore important to examine the problems associated with the curriculum dissemination course so that existing weaknesses are improved so that the curriculum is effectively disseminated.

\section{Facilities: manpower, teaching material and resources}

The study revealed that headmasters, senior assistants of curriculum and History teachers encountered challenges when managing and implementing curriculum change at school level. Findings from Tamil Type National Primary School's History teachers expressed the problem in terms of the lack of teaching materials, financial resources and manpower. Lack of teaching material refers to lack of history charts, exercise books and teacher's guidebooks. Teachers from Tamil Type National Primary School found it difficult to get workbooks in shops for History subject compared to National School and Chinese Type National School for whom workbooks available in abundance in shops. Other than that, teachers from National Primary School and Tamil Types National Primary Schools are having problems in implementing History Subject without Teachers Guide Books. Besides that, lack of financial allocation causes problems for teachers in National Primary School and Tamil Type National Primary school in buying History subject charts which are expensive to purchase. Furthermore, lack of skilled teachers for teaching History subject is a problem in all types of primary schools. It is happened because MOE introduced the History Subject starts from Year Four without providing the skilled teachers to teach History in primary schools. Next, senior assistant of curriculum from National Primary School expressed the problem in terms of lacking teaching material such as ICT facilities and problems in distribution of History textbooks in the rural area of Sabah and Sarawak. Besides that, senior assistant of curriculum from Tamil Type National School encountered problems in terms of lack of financial resources to manage the History Committee activities and reported that teachers are having problems in translating Curriculum and Assessment Standard Documents for History Subject in Tamil Language since that document provided in National language only. 


\section{Monitoring}

Monitoring is an essential aspect of any curriculum change. It is essential to gather data on on the implementation or management of the curriculum so as to keep abreast of the developments and to continuously improve the curriculum and its management. Findings from a officer from Curriculum Development Division from the school observation indicate that teachers who were not historical options did not understand the History curriculum. This led to the ineffectiveness of the teaching and learning process. Besides that, according to National Trainer and the officer from DEO, there was insufficient manpower to observe the implementation of History in the district of Kuala Selangor which consists of 71 schools. Lack of monitoring by officers at the district level causes problems in schools less monitored. Therefore, many monitoring officers need to be deloyed at the District Education Office.

\section{Conclusion}

In conclusion, the problems studied in this study are related to the management of curriculum changes, namely how the desired curriculum and written curriculum can be translated into the process of implementation of aspects of content, teaching and learning process and assessment. This refers to the alignment between the written curriculum and the curriculum practiced. If there is no alignment between the written curriculum, the taught curriculum and the assessed curriculum, the goal of the curriculum change in producing first-class human capital will not be achieved. Hence, an understanding of curriculum change and curriculum change management is crucial for all stakeholders involved in the Malaysian education system. Curriculum change will be successful if it is planned and implemented systematically based on a proper curriculum change management strategy. This means there should be an assessment of the management of primary school curriculum changes by identifying the advantages and addressing the existing weaknesses in the current curriculum so that there is no disjuncture between the designed and operationalized curriculum. According to Stenhouse (1975), the central problem of curriculum study is the gap between our ideas and aspirations and our attempts to operationalize them.

\section{References}

Blenkin, G. M., Edwards, G. \& Kelly, A.V. (1992). Change and the Curriculum. London: Paul Chapman.

Bernstein, B. (2003). Class codes and control, towards a theory of educational transmissions ( $3^{\text {rd }}$ ed.). London: Psychology Press.

Hibbard, L., Leonard, R. \& Pai, A. (2015, November 2015). Curriculum Design for Equity and Excellence, presented at Advancing Social Justice from Classroom to Community, New York University. Retrieved from https://www.researchgate.net/publication/305280544.

Keller, M. M., Neumann, K., \& Fischer, H. E. (2017). The impact of physics teachers' pedagogical content knowledge and motivation on students' achievement and interest. Journal of Research in Science Teaching, 54(5), 586-614. Retrived from https://doi.org/10.1002/tea.21378.

Ljubojevic, M., Vaskovic, V., Stankovic, S., \& Vaskovic, J. (2014). Using supplementary video in multimedia instruction as a teaching tool to increase efficiency of learning and quality of experience. The International Review of Research in Open and 
Distributed Learning, 15(3). Retrieved from http://www.irrodl.org /index.php/irrodl/ article/view/1825.

Majoni, C. (2017). Curriculum Overload and its Implication on Teacher Effectiveness in Primary Schools. European Journal of Education Studies, 3(3), 155-162. Retrieved from https://oapub.org/ edu/index. php/ ejes/article/view/516/1418 .

Ministry of Education of Malaysia. (1988). Cabinet Committee Report on the Review of the Implementation of The Education Policy. Kuala Lumpur: Ministry of Education Malaysia.

Ministry of Education Malaysia. (2010). Explanations Book for Standard Based Primary School Curriculum. Putrajaya: Curriculum Development Division.

Ministry of Education Malaysia. (2012). Early Report Malaysia's Education Blueprint 2013 2025. Putrajaya: Ministry of Education Malaysia.

Ministry of Education Malaysia. (2013). Curriculum and Assessment Standard Documents Year Four History Subject. Putrajaya: Curriculum Development Division.

Ministry of Education Malaysia. (2014). Higher Order Thinking Skills. Application in Schools. Putrajaya: Curriculum Development Division.

Nor Haslynda Abdul Rahman. (2014). From Curriculum Reform to Classroom Practice: An Evaluation of the English Primary Curriculum in Malaysia (Doctoral Thesis). United Kingdom: University of York.

Ratnavadivel, N. (1995). The Management of Innovation: An evaluation of curriculum change in Malaysian Teacher Education (Doctorol Thesis). United Kingdom: University of East Anglia. (n.published)

Stake, R.E. (1967). The countenance of educational evaluation. Teachers College Record, 68 (7), 523-540.

Stabback, P. (2015). What makes a Quality Curriculum. In Progress Reflection, (2), 1-41. Retrived from http://unesdoc.unesco.org/images/0024/002439/243975e.pdf.

Stenhouse. (1975). An Introduction to Curriculum Research and Development. London: Heinemann

Walker, C.T. (2016). Investigating The Pedagogical Content Knowledge of Outdoor Education Teachers (Doctoral Dissertation). Australia: University of Tasmania. Retrieved from https://eprints.utas.edu.au/23538/.

William, F.O., Yahaya, L., \& Owolabi, H. (2018). Teachers Knowledge Indices s Predictors of Secondary School Student's Academic Achievement in Kwara State, Nigeria. Journal of Education, 6(1), 73-90. Retrieved from https://files.eric.ed.gov/fulltext/EJ1172016.pdf. 